\section{DEVELDPMENT AND}

\section{APPLICATION DF THE \\ PRACTICAL DN-SITE \\ CDIPERATION MODEL (PDCDM) \\ FOR IMPRDVING SCIENCE \\ TEACHING IN SECDNDARY \\ SCHOOLS}

\author{
Jongwon Park, \\ Youngmin Kim, \\ Young-Shin Park, \\ Jongseok Park, \\ Jin-Su Jeong
}

\section{Introduction}

This study aimed to identify practical methods for improving science teaching and learning. Science teaching and learning have been improved through a reformed science curriculum, the development of various teaching models and materials, and in-service teacher training courses that develop teaching expertise. However, not all of these efforts have yielded success (Eijkelhof \& Kapteijn, 2000; Larkin, Seyforth, \& Lasky, 2009; Southerland, Smith, Sowell, \& Kittleson, 2007; Supovitz \& Turner, 2000).

Unsuccessful results have been attributed to many reasons, one of which is the inability of educational policy to recognize the actual teaching environment of the classroom. For example, Barton (1998) argued that educational policy emphasizing "science for all" was difficult to implement among all students in all schools because it did not reflect the realities of the classroom and the lives of students. Moreover, even though a policy that promotes a new direction in science education may be well constructed, the practical link from policy to practice may not be appropriate (Chisholm \& Leyendecker, 2008). Therefore, while most teachers agree with the aims of the reforms, actual conditions for supporting a new approach are not provided in schools. Johnson (2006) found that middle school science teachers recognized various environmental barriers to standard-based instruction, such as insufficient time for planning, inadequate in-service programs and teaching resources, and evaluation pressures.

Another critical factor leading to successful reform is the teacher. Many recognize that teachers are the key to reform success (Bantwini, 2010). However, science teachers often depend on traditional teacher-directed instruction (Banilower, Boyd, Pasley, \& Weiss, 2005). They are either unable or unwilling to change their teaching style to support reform-based approaches (Davis, 2002), or they use reformed curriculum materials only to a limited extent or
Abstract. This study aimed to improve science teaching in a practical way by activating teachers' potential teaching expertise or professional knowledge. We developed an alternative in-service approach, the Practical On-site Cooperation Model (POCOM), according to the following principles: (1) the "bottom-up" approach, where observed problems in science classes are improved practically and immediately without any pre-determined teaching plan or materials; (2) "cooperation" between researchers and teachers to improve teaching; (3) "naturalistic settings" where various real problems occur in actual teaching and learning situations; and (4) "gradual improvement" rather than revolutionary change. The POCOM was applied with three science teachers, and 24 classes were observed. We found about 65\%-96\% teaching improvement. The analysis of the cooperation processes and science teaching in classrooms identified seven types of successful improvements and five types of unsatisfactory cases, including their reasons and features.

Key words: cooperative model, in-service teacher, observational protocol, professional development, science teaching.

Jongwon Park

Chonnam National University, Gwangju, Korea Youngmin Kim

Pusan National University, Busan, Korea Young-Shin Park Chosun University, Gwangju, Korea Jongseok Park Kyungpook National University, Daegu, Korea Jin-Su Jeong

Daegu University, Gyeongbuk, Korea 
with different aims from those of the curriculum developers (Penuel, Fishman, Gallagher, Korbak, \& Lopez-Prado, 2009). Therefore, many educators are concerned about the degree to which science teachers recognize the value, intention, or goal of the reformed curriculum and whether they have the adequate expertise or professional skills required to implement the reformed approach successfully, such as constructivist, inquiry-based, or studentcentered teaching skills.

Moreover, many studies have reported the ineffectiveness of pre- and in-service training courses for teachers' professional development. For example, Joram and Gabriele (1998) reported that many pre-service teachers considered the educational psychology courses at universities to have unimportant content for the teachers' training program. Hobson, Malderez, Tracey, Giannakaki, Pell, and Tomlinson (2008) observed that some prospective teachers considered what they learned at the university (or higher education institutes) as being only partially useful to their actual classroom teaching or to their "being a teacher" in the future. Putnam and Boroko (2000, p. 6) also noted that many teachers complained that learning in the training course was "too removed from the dayto-day work of (their) teaching."

As a result, to improve science teaching in schools under a reformed policy, we need an alternative in-service teacher training program that links the reformed curricula with practice and also takes into account the reality of the teaching and learning context and status of science teachers. In this study, we first considered the status of Korean science teachers.

\section{Science Teachers in Korea}

In Korea, teaching is considered one of the most favourable jobs. Therefore, many highly qualified high school students want to attend colleges of education. To become science teachers, students must pass the national recruitment examination after graduating from college. Since this examination is very competitive (the competition rate ranged from 7:1 to 12:1 for each science major in 2013), students usually study rigorously in college (Park, Park, Kim, Jeong, \& Park, 2014). Thus, we might expect that the level of Korean science teachers' knowledge and skills about teaching would be very high. However, Park, Park, Kim, Jeong, and Park (2014) found that Korean science teachers implemented only $26 \%$ of their knowledge about educational theories and teaching strategies in practice.

In this paper, we focus on this gap between the teachers' potential expertise and actual teaching in the classroom. That is, we expect that if the science teachers' existing but embedded teaching expertise can be activated in their actual classroom and laboratory teaching, then the aims of the reformed science teaching and learning policy would be achieved.

The chief goal of our approach is to improve everyday science teaching under ordinary conditions without using any special pre-developed teaching plan and materials or a specially organized teaching circumstance. This approach is based on the assertions that programs for teacher education should contribute to the development of actual classroom teaching (Ostermeier, Prenzel, \& Duit, 2012) and that their isolation from the realities of school and the classroom can lead to the failure of reformed teaching (Buczynski \& Hansen, 2010).

\section{Purposes of Research}

To improve science teaching in a practical way by connecting science teachers' teaching expertise with their actual teaching practice in classrooms, we set the specific purposes of this study as follows:

- to develop an alternative approach: the Practical On-site Cooperation Model (POCoM);

- to apply the POCoM to improve science teaching in junior high schools;

- to analyze the effectiveness of the POCoM application;

- to investigate the various characteristics of teaching and learning during the POCoM application.

\section{The POCoM as an Alternative Approach to Improving Science Teaching in the Classroom}

\section{Four Basic Principles of the POCOM Development}

To develop the POCOM, the following four basic principles were adopted. First, we adopted the "bottom-up" approach. In a "top-down" approach, the academic professional conducts research to develop a teaching theory and strategy and gives these teachers to apply in their actual classroom teaching. The top-down approach assumes 
that "if teachers learned the theories or various effective teaching skills well in a pre- or in-service course, then they would use or apply what they learned in their school teaching" (Wallace \& Louden, 1992). However, actual teaching is complex and unpredictable (Hoban, 2005). Therefore, any one specific educational theory or teaching strategy cannot be applied in the same way in all teaching situations (Loughran, Berry, \& Mulhall, 2006, p. 9). This means that good teaching requires more than the use of educational theories or pre-scheduled teaching methods (Hascher, Cocard, \& Moser, 2004; Wallace \& Louden, 1992). That is, in addition to theory, it is also critical to consider more practical and context-dependent information, such as classroom conditions and facilities, students' learning level, their interests and culture, and teachers'teaching experience and style. Therefore, we adopted the bottom-up approach, where we observed several ordinary science classes directly and then tried to improve them without any pre-determined or pre-developed teaching methods or materials.

Second, the approach of this study emphasized cooperation between professional educators and science teachers. When improving the science classes, we encouraged the teachers to develop alternative teaching methods by themselves to improve their science teaching. To do this, the teachers needed to have professional expertise to develop new teaching methods and evaluate their effectiveness (Hiebert, Gallimore, \& Stigler, 2002). However, we cannot assume that all science teachers have such professional expertise; therefore, we cooperated with the science teachers to help them improve their classes.

Here, it is worth mentioning that the suggestions for improvement should be "theory-based" and "evidencebased" (Bednar, Cunningham, Duffy, \& Perry, 1995; Hascher et al., 2004; Kearns et al., 2010), rather than based on personal experiences, intuitions, or fashions and trends. This is because of Slavin's (2008) criticism that "the adoption of instructional programs and practices has been driven more by ideology, faddism, politics, and marketing than by evidence."

Third, the approach is based on a naturalistic (in vivo) rather than an experimental (in vitro) method. In the latter case, educators usually conduct controlled experiments to investigate the effectiveness of a developed teaching approach. In this case, a researcher determines the new teaching approach, including the independent variables, and then tests their effectiveness using a control group. To do this, other variables that were not selected as independent ones should be strictly controlled.

However, a teaching method constructed for a particular situation can never be sufficiently concrete and precise to account for all situations because teaching contexts are different and complex (Trianou, 2007, p. 37). Therefore, teaching strategies need to be flexible and context-dependent, and should be able to work with various types of classrooms, including different classroom conditions and facilities, teachers' teaching styles and perceptions of teaching goals, students' academic levels and interests, and other various conditions. This study adopted a naturalistic or in vivo approach (Dunbar, 2001) to identify real features of specific science teaching in a real classroom or laboratory and to observe actual and instant responses as well as their effects in a naturalistic setting without controlling any variables. Moreover, this naturalistic approach emphasized the importance of context-dependent knowledge and skills that can be used in actual and complex classroom teaching (Banks, Mayes, Oakes, \& Sutton, 2001), instead of abstract, systematized, and general-expert knowledge about science teaching and learning. In addition, it highlighted practical knowledge that "consists of teachers' knowledge and beliefs about their own teaching practice, and is mainly the result of their teaching experience" (van Driel, Beijaard, \& Verloop, 2001, p. 138). Given that practical knowledge develops by "participating in and reflecting on a teacher's own action and experience, ... it enables teachers to deal effectively with practical problems" (Korthagen, 2007, p. 306).

To determine how much the teachers who participated in this study improved their teaching in the naturalistic settings, we developed and employed an observation protocol checklist, the Korean Teaching Observation Protocol (KTOP), which considered the context of science teaching and learning in Korean schools. Detailed information on the KTOP is presented in the next section and in another paper (Park, Park, Kim, Park, \& Jeong, 2014).

Fourth, we aimed for gradual improvement rather than revolutionary improvement of science teaching. Educational studies usually demonstrate the effectiveness of a new teaching method by comparing the initial state and the final state of students' achievement. In this case, even though a statistical difference may show the effectiveness of a new method, the new method will always accompany unsatisfactory and unexpected elements because of various prohibiting factors embedded in the application settings. Therefore, after the first application, it is necessary to identify any difficulties that arose during the first application process. Revising the original strategies by adjusting the difficulties found in the first application can enhance then the next application (Park \& Han, 2002). Therefore, through this kind of repetitive or cyclical application of a new teaching method, we assume gradual improvement in teaching from class to class. 
(P. 45-63)

To promote the cyclical process of improvement, we need a special teaching situation. If the total number of students in a grade is 100 and there are 25 students in a class, then a teacher would teach the same science content in four different classes. In this situation, after the first improvement effort, the science teacher has two more opportunities through which he/she can revise the previous teaching methods. Figure 1 shows the POCoM developed according to the above four basic principles.

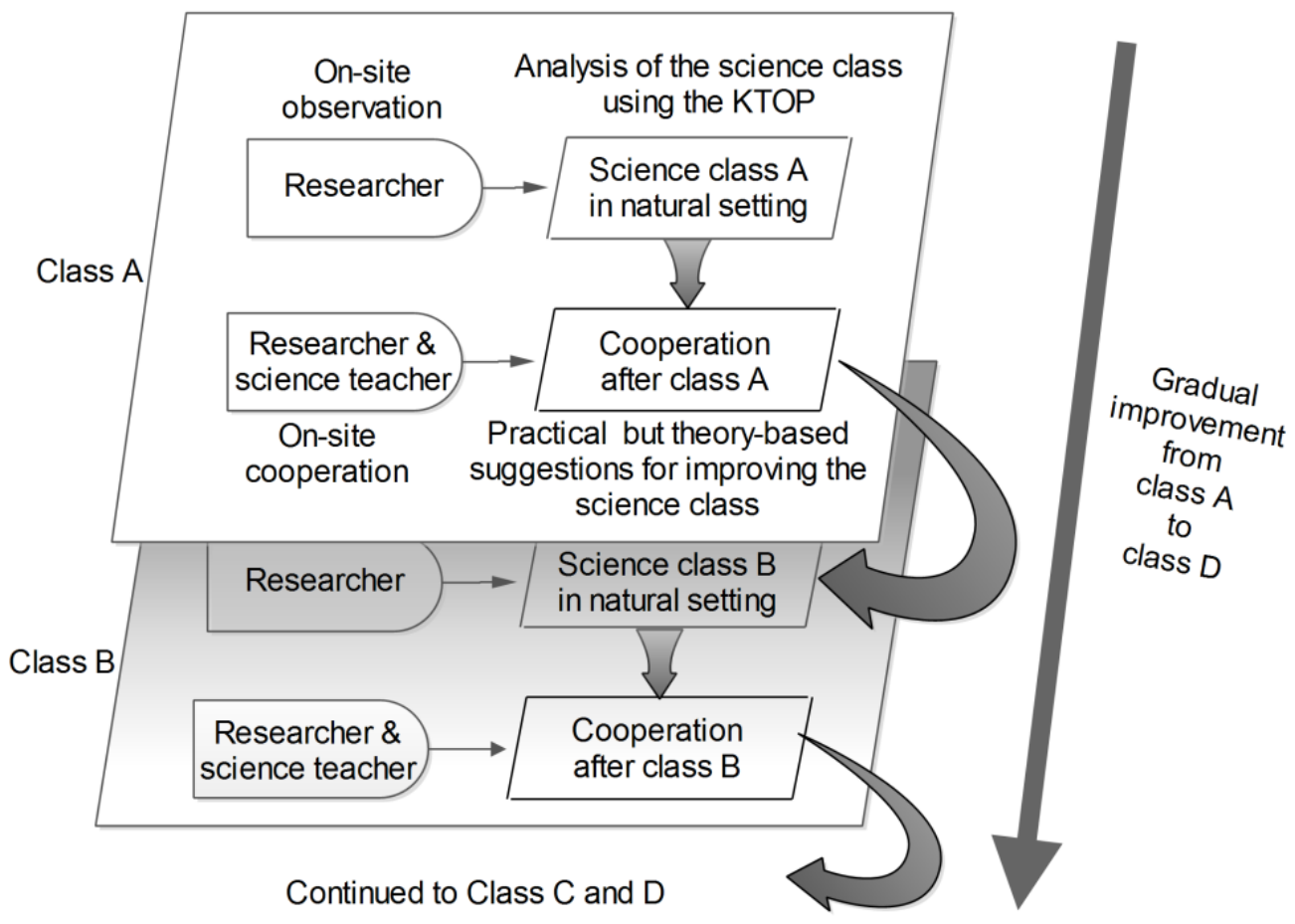

Figure 1: The Practical On-site Cooperation Model (POCoM).

\section{The Korean Teaching Observation Protocol (KTOP)}

To identify the teaching and learning components that needed improvement, we developed the KTOP (Park, Park, Kim, Park, \& Jeong, 2014). The KTOP consists of 4 main categories, 10 sub-categories and 30 items, as shown in Table 1. For each item, an operational definition is provided in addition to counterexamples corresponding to the teaching situation that needs to be improved and exemplary examples indicating an improved teaching situation. More details about the process, validity and reliability, and major features of the KTOP can be found in Park, Park, Kim, Park, and Jeong (2014). 
Table 1. Korean Teaching Observation Protocol (KTOP).

\begin{tabular}{|c|c|c|}
\hline \multicolumn{2}{|c|}{ Category } & Item \\
\hline Philosophy & 1. Constructivism & 1.1 Students are on task actively in class. \\
\hline & & 1.2 Students realize the objectives and products of class activities metacognitively. \\
\hline & & 1.3 Teacher, as a supporter, facilitates students' learning, not directs it. \\
\hline \multirow[t]{18}{*}{ Goals of Learning } & $\begin{array}{l}\text { 2. Nature of } \\
\text { Science }\end{array}$ & 2.1 Teacher helps students understand the nature of science. \\
\hline & \multirow[t]{6}{*}{$\begin{array}{l}\text { 3. Concept } \\
\text { Understanding }\end{array}$} & $\begin{array}{l}\text { 3.1 Teacher encourages students to reflect on their prior knowledge and employs a conceptual } \\
\text { change model if there are any misconceptions. }\end{array}$ \\
\hline & & 3.2 Teacher explains core concepts appropriately and accurately. \\
\hline & & $\begin{array}{l}\text { 3.3 Teacher makes difficult and abstract concepts (including graphs, codes, and symbols) more } \\
\text { understandable and easy. }\end{array}$ \\
\hline & & $\begin{array}{l}\text { 3.4 Students model and construct their own understanding through active exploration and infer- } \\
\text { ence activities. }\end{array}$ \\
\hline & & 3.5 Students reflect on their own or other students' understanding metacognitively. \\
\hline & & $\begin{array}{l}\text { 3.6 Students extend their basic understanding about concepts to a more complicated and wider } \\
\text { scope. }\end{array}$ \\
\hline & \multirow{7}{*}{$\begin{array}{l}\text { 4. Scientific } \\
\text { Inquiry }\end{array}$} & 4.1 All materials are prepared before lab activity, and students clean up after lab activity. \\
\hline & & 4.2 Teacher provides lab safety instructions to students before and during experimentation. \\
\hline & & $\begin{array}{l}\text { 4.3 Teacher checks students' existing inquiry skills and provides appropriate instruction for revising } \\
\text { them if necessary. }\end{array}$ \\
\hline & & 4.4 Students realize the inquiry process metacognitively rather than blindly follow a procedure. \\
\hline & & $\begin{array}{l}\text { 4.5 Teacher instructs students to develop inquiry skills in more detail if necessary, such as skills of } \\
\text { observation, variable control, or hypothesizing. }\end{array}$ \\
\hline & & $\begin{array}{l}\text { 4.6 Students evaluate the experimental results by comparing them with the hypothesis and infer- } \\
\text { ring reasons for errors. }\end{array}$ \\
\hline & & $\begin{array}{l}\text { 4.7 Students carry out various types of inquiry activities, such as inductive or hypothesis-deductive } \\
\text { activities. }\end{array}$ \\
\hline & \multirow{3}{*}{$\begin{array}{l}\text { 5. Scientific } \\
\text { Thinking } \\
\text { Development }\end{array}$} & $\begin{array}{l}\text { 5.1 Teacher encourages students to develop or employ scientific thinking (deductive, inductive, } \\
\text { and abductive thinking) in class. }\end{array}$ \\
\hline & & $\begin{array}{l}\text { 5.2 Students have a chance to develop their claims by discussion or argumentation with support- } \\
\text { ing evidence. }\end{array}$ \\
\hline & & 5.3 Teacher encourages creative thinking through various activities. \\
\hline & $\begin{array}{l}\text { 6. Motivation } \\
\text { and Interest }\end{array}$ & 6.1 Teacher motivates/interests students in their learning. \\
\hline \multirow[t]{8}{*}{ Activities } & \multirow[t]{2}{*}{ 7. Connection } & 7.1 Teacher integrates content with other classes or interdisciplinary curricula. \\
\hline & & $\begin{array}{l}\text { 7.2 Students apply what they learned to various contexts (daily life, engineering/technology, or } \\
\text { environmental situations). }\end{array}$ \\
\hline & \multirow{3}{*}{$\begin{array}{l}\text { 8. Learning } \\
\text { Strategies/ } \\
\text { Tools }\end{array}$} & 8.1 Students use various learning strategies such as analogy, concept mapping, and so on. \\
\hline & & $\begin{array}{l}\text { 8.2 Various appropriate media such as computer, graphics, drawings, video, demonstration, and } \\
\text { so on, are used. }\end{array}$ \\
\hline & & $\begin{array}{l}\text { 8.3 Students participate actively in various learning activities such as worksheet activities, games, } \\
\text { or role plays. }\end{array}$ \\
\hline & \multirow{3}{*}{$\begin{array}{l}\text { 9. Cooperation } \\
\text { and } \\
\text { Communication }\end{array}$} & 9.1 Teacher encourages students to be cooperative in learning through group activities. \\
\hline & & 9.2 Students communicate with teacher or with one another through discussion and presentation. \\
\hline & & $\begin{array}{l}\text { 9.3 Students ask and answer questions actively, and the teacher responds to spontaneous ques- } \\
\text { tions appropriately. }\end{array}$ \\
\hline Assessment & 10. Assessing & 10 Teacher assesses whether learning objectives are met during the class. \\
\hline
\end{tabular}




\section{Methodology of Research}

\section{Participants}

For the study, three science teachers (physics, biology, and earth science) and three middle schools were selected and participated voluntarily. The teachers were asked to teach the same science content in four different classes. The school principals permitted the researchers to observe and cooperate with the teachers. All three teachers who volunteered to participate in the POCOM were female, with an average of 7.3 years of teaching experience.

\section{Teaching Context for Research}

Physics class: The main topic of the physics class was the refraction of light. The students learned that the refraction of light occurs according to the least time principle (that is, light is refracted according to the path that takes the least time) or the change of velocity of light. They also drew the path of light propagation, comparing the incident angle with the refracted angle, and explained various natural phenomena regarding the refraction of light, such as a "broken pencil" submerged in water and mirages.

Biology class: The main topic of the biology class was the generation and use of (biological) energy. The students learned the similarities and differences between cellular respiration and combustion, that is, that cellular respiration and combustion use oxygen to generate energy and produce water and carbon dioxide, and that combustion reacts rapidly but cellular respiration progresses slowly as the cells use the energy generated by cellular respiration. They also learned about how biological energy is used for living.

Earth science class: The main topic of the earth science class was how to connect the sun's apparent motion with the star constellations' annual motion by the earth's revolution. The students learned about each zodiac sign and tried to understand each position of the sun and their own corresponding birth constellation, whose positions were opposite each other. The teacher used drawings, constellation-related songs, and role play so that the students could understand why their own birth constellations were not assigned to the month in which they were born.

\section{The Overall Process of Applying the POCOM}

The overall process of the POCoM application is described in Figure 2.

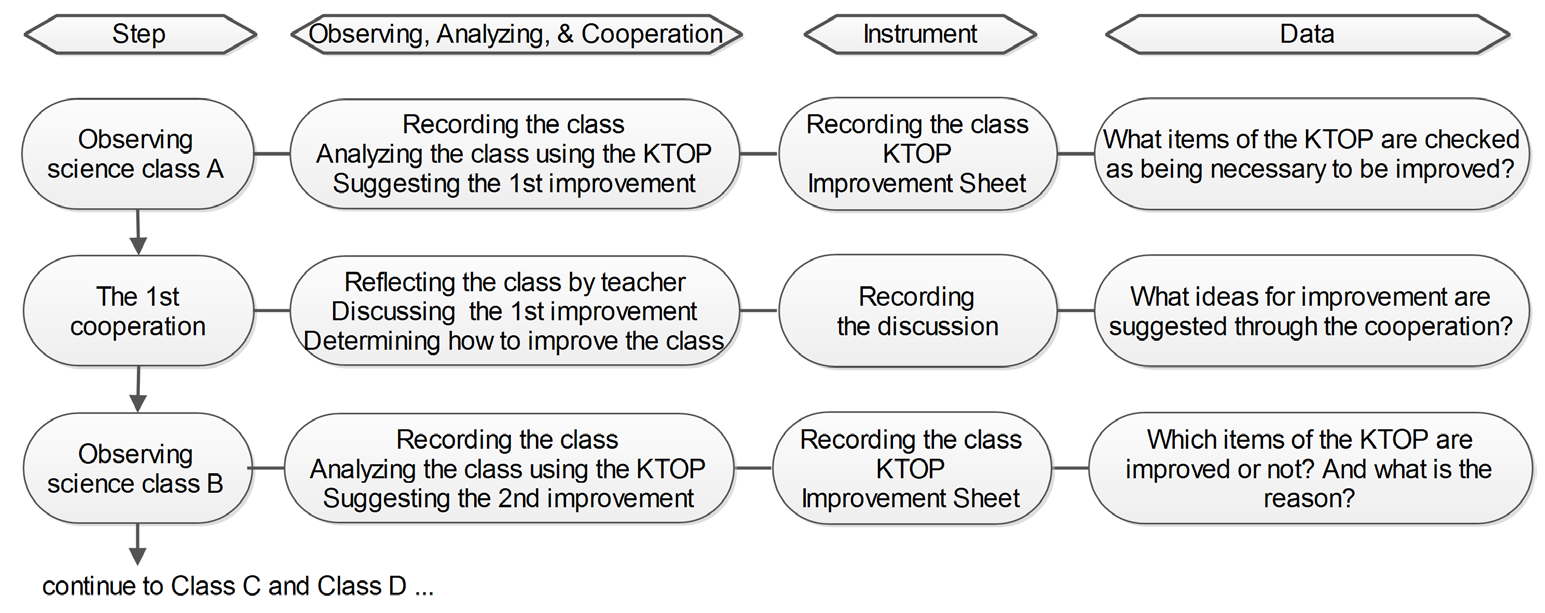

\section{Figure 2: Overall process of the POCoM.}

Before the science class observations, the goal of the study was introduced to the three participating science teachers. They were asked not to make any special preparations for their science classes but to demonstrate ordinary science teaching in a naturalistic setting.

Each researcher observed one assigned teacher during the classes. The researcher recorded the entire lesson 
as a non-participant observer without interrupting the teacher's teaching or students'learning. Without asking the students questions, the researcher simply observed and analyzed the class. The analysis was done using the KTOP and the "Improvement Sheet," which was designed to describe the teaching that needed to be improved and to note the researcher's ideas about how the class could be improved. For example, if the researcher found that "there were no student activities except textbook reading" for Item 1-1 on the KTOP (Figure 3), then he could suggest improvements, like "The teacher can encourage students to draw the rays of refraction by themselves (when they have learned the content about the refraction of light) and have the students evaluate each other's drawings."

\begin{tabular}{|c|c|c|}
\hline \multicolumn{3}{|c|}{ Class(physics classroom-1), Date(00), Teacher(00), Analyzer(000) } \\
\hline \multicolumn{2}{|c|}{ Result of Analysis } & \multicolumn{1}{c|}{ Suggestions for Improvement } \\
\hline Item & Unsatisfactory Aspect & $\begin{array}{l}\text { Teacher needs to encourage students to } \\
\text { draw the rays of refraction by themselves, } \\
\text { students' activities except } \\
\text { reading a textbook. } \\
\text { other's drawings. }\end{array}$ \\
\hline$\ldots$ & $\ldots$ & $\ldots$ \\
\hline
\end{tabular}

Figure 3: An example of the Improvement Sheet.

Immediately after the first class, the researcher and science teacher as a pair met in a quiet and comfortable space such as a vacant laboratory or meeting room to discuss the results and ideas of the researcher's analysis for teaching improvement. First, the science teacher reflected on his/her own teaching without watching the recorded video, and then the researcher presented ideas about some aspects of his/her teaching that needed to be improved on the basis of the KTOP analysis. The researchers did not evaluate the science teachers' teaching to find mistakes or faults. Rather, the researcher merely made suggestions for improving certain aspects of the teaching to enhance students' learning. In addition, when suggesting the ideas for improvement, the researchers did not force the science teachers to change their teaching but instead encouraged them to devise their own methods or to choose and modify the suggested ideas for improvement. Sometimes, the researcher and the assigned teacher had an open discussion or debate about specific topics, such the basic goal of teaching, educational philosophy, and fundamental teaching styles.

In the next class, the science teacher tried to change his/her teaching method by applying the ideas for improvement discussed in the cooperative meeting. During the second observation (i.e., in the second class), the researcher used the KTOP again and afterward met with the teacher to discuss the results of implementation and then suggest more improvements for the third class. Through this cyclical process, the researcher investigated the process of the teacher's efforts in improving his/her teaching in the subsequent classes and the reasons some teaching strategies could be improved and others could not.

This cyclical process spanned four classes and was conducted within a few days. After conducting the first cycle of the POCoM application, the next cyclical application was carried out again after 10-50 days with the same three teachers. This was done to check whether the POCoM effectiveness obtained in the first application was also found in the changed class. The second application of the POCoM was exactly the same as the first application shown in Figure 2, except for the teaching contents and use of the questionnaire.

\section{Video-recording the Science Class and Cooperation Process}

We video-recorded four classes each for physics, biology, and earth science, for a total recording of 12 classroom hours. After the teaching, meetings were held to discuss ways to improve the next class. There were three meetings each for physics, biology, and earth science, for a total recording of nine times of meeting. The average recording time per meeting was about 26 minutes. As a result, the total number of recorded videos was 21 (12 classroom observations and 9 meetings). All of these recordings were transcribed and analyzed.

The process above was repeated in the second cycle after 10-50 days, as mentioned earlier. Therefore, the total number of recordings transcribed and analyzed was 42 . 


\section{Results of Research}

\section{The KTOP Items Checked as Requiring Improvement}

Table 2 shows the KTOP items were checked as requiring improvement during the classroom observation. In Table 2, "P," "B," and " $E$ " mean physics, biology, and earth science teaching, respectively. The number " 1 " in each cell means that "the item should be improved" and " 0.5 " that "the item was partially improved." The number " 0 " means that "the item was improved." Vacant cells in Table 2 mean that there were no comments about improvement because the teaching and learning related to that item were already good or the item had no relevance to the class. For example, all items for "Item 4. Scientific Inquiry" in Table 1 were omitted because the teaching in this study was performed only in a classroom without laboratory activities.

Table 2. The KTOP items checked as requiring improvement.

\begin{tabular}{|c|c|c|c|c|c|c|c|c|c|c|c|c|c|c|c|c|}
\hline & & \multirow{3}{*}{ Item } & \multicolumn{12}{|c|}{ Class } & \multirow{2}{*}{\multicolumn{2}{|c|}{$\begin{array}{c}\text { Sum } \\
\text { (average per class) }\end{array}$}} \\
\hline \multicolumn{2}{|l|}{ Category } & & \multicolumn{3}{|c|}{$1 s t$} & \multicolumn{3}{|c|}{ 2nd } & \multicolumn{3}{|c|}{ 3rd } & \multicolumn{3}{|c|}{ 4th } & & \\
\hline & & & $\mathbf{P}$ & B & $\mathbf{E}$ & $\mathbf{P}$ & B & E & $\mathbf{P}$ & B & $\mathbf{E}$ & $\mathbf{P}$ & B & $\mathbf{E}$ & & \\
\hline \multirow[t]{3}{*}{ Philosophy } & 1. & $1-1$ & 1 & 1 & 1 & 0.5 & 1 & 1 & 0 & 0 & 1 & 0 & 0 & 1 & 7.5 & $14.5(1.2)^{*}$ \\
\hline & & $1-2$ & & 1 & 0 & & 0.5 & 0 & & 0 & 0 & & 0 & 0 & 1.5 & \\
\hline & & $1-3$ & 1 & & 1 & 0.5 & & 0.5 & 0.5 & & 1 & 0.5 & & 0.5 & 5.5 & \\
\hline \multirow[t]{11}{*}{ Goals of Learning } & 2. & 2 & & 1 & 1 & & 1 & 0.5 & & 1 & 0.5 & & 0 & 0.5 & 5.5 & $5.5(0.5)$ \\
\hline & 3. & $3-1$ & & 1 & & & 0 & & & 0 & & & 0 & & 1.0 & $14.5(1.2)$ \\
\hline & & $3-2$ & 1 & & 1 & 0 & & 0.5 & 0 & & 0 & 0 & & 0 & 2.5 & \\
\hline & & $3-3$ & 1 & 1 & & 0.5 & 1 & & 0.5 & 1 & & 0 & 0 & & 5.0 & \\
\hline & & $3-4$ & 1 & & 1 & 0 & & 0.5 & 0 & & 0 & 0 & & 0 & 2.5 & \\
\hline & & $3-5$ & & & & & & & & & & & & & & \\
\hline & & $3-6$ & & 1 & 1 & & & 0.5 & & & 0.5 & & & 0.5 & 3.5 & \\
\hline & 5. & $5-1$ & & & & & & & & & & & & & & \\
\hline & & $5-2$ & & & & & & & & & & & & & & $2.5(0.2)$ \\
\hline & & $5-3$ & & 1 & & & 1 & & & 0.5 & & & 0 & & 2.5 & \\
\hline & 6. & 6 & 1 & 1 & & 1 & 1 & & 1 & 0.5 & & 0 & 0 & & 5.5 & $5.5(0.5)$ \\
\hline \multirow[t]{8}{*}{ Activities } & 7. & $7-1$ & & & & & & & & & & & & & & $0.0(00)$ \\
\hline & & $7-2$ & & & & & & & & & & & & & & \\
\hline & 8. & $8-1$ & & & & & & & & & 1 & & & 1 & 2 & \\
\hline & & $8-2$ & 1 & 1 & & 0.5 & & & 0.5 & & & 0 & & & 3.0 & $8.0(0.7)$ \\
\hline & & $8-3$ & 1 & 1 & & 0 & 0.5 & & 0 & 0.5 & & 0 & 0 & & 3.0 & \\
\hline & 9. & $9-1$ & 1 & 1 & 1 & 0.5 & 0.5 & 0 & 0.5 & 0 & 0 & 0 & 0 & 0 & 4.5 & \\
\hline & & $9-2$ & 1 & 1 & & 1 & 0.5 & 1 & 0 & 0.5 & 0 & 0 & 0.5 & 0 & 5.5 & $17.0(1.4)$ \\
\hline & & $9-3$ & 1 & 1 & 1 & 1 & 0 & 1 & 1 & 0 & 0 & 1 & 0 & 0 & 7.0 & \\
\hline Assessment & 10. & 10 & 1 & 1 & & 0 & 0 & & 0 & 0 & & 0 & 0 & & 2 & $2.0(0.2)$ \\
\hline \multirow{2}{*}{\multicolumn{3}{|c|}{ Sum (average per class) }} & 12 & 14 & 8 & 5.5 & 7 & 5.5 & 4 & 4 & 4 & 1.5 & 0.5 & 3.5 & \multirow[t]{2}{*}{69.5} & \\
\hline & & & 34 & & & 18 & & & $12(4$ & 4.0) & & 5.5( & (1.8) & & & \\
\hline
\end{tabular}

* Numbers in parentheses are the average per class.

The findings from Table 2 are as follows. First, in the first class, 11.3 items (49\%) out of 23 items were checked as requiring improvement. This number also means that, during classroom observation, the average number of items that a researcher can check is about 11.3. 
Second, eight categories of the KTOP were checked. Among them, Category 9 was checked as requiring the most improvement (average number of items per class was 1.4). Categories 1 and 3 were also checked as requiring improvement in nearly every class, because the average number of items in these categories requiring improvement per class was 1.2 .

Third, the number of items requiring improvement decreased from the first class to the fourth class (that is, $11.3 \rightarrow 6.0 \rightarrow 4.0 \rightarrow 1.8)$. A comparison of the first and fourth classes showed that $84.1 \%\left((11.3-1.8) / 11.3^{*} 100\right)$ of items checked as requiring improvement in the first class were improved in the fourth class.

Fourth, four items were still checked as being partially improved in the fourth class: Items 1-3 (Teacher as a supporter), 2 (Teaching the NOS), 3-6 (Extending students' basic understanding), and 9-2 (Students' active communication).

Fifth, three items were not improved at all, despite three separate efforts by the researcher and the teacher's cooperation for improving teaching: Items 1-1 (Students are on task actively in class), 8-1 (Using various teaching strategies), and 9-3 (Active asking and answering the questions). These cases show that special consideration is needed to determine how to give more concrete and practical guides for improvement.

Finally, as mentioned earlier, some items, such as Item 5-2 (Developing a claim through discussion or argumentation), were not checked as requiring improvement because it was judged that the observed classes did not require any argumentation activity. Additionally, some items were judged to be good already. For example, in the first physics class about the refraction of light, the teacher used various contexts such as a rainbow, mirage, and chopsticks immersed in a cup of water. This is related to item 7-1 (Integrating contents). Therefore, the cell for Item 7-1 of the physics class was left vacant.

\section{Overall Improvement}

Figure 4 is a graphical representation of the overall improvement of the physics class as an example. In the figure, black indicates "requiring improvement," dark gray "partially improved," and light gray "improved" through cooperation.

\begin{tabular}{|c|c|c|c|c|c|c|}
\hline \multirow{2}{*}{\multicolumn{2}{|c|}{ Category }} & \multirow{3}{*}{$\begin{array}{r}\text { Item } \\
1-1\end{array}$} & \multicolumn{4}{|c|}{ Physics Class } \\
\hline & & & \multirow{2}{*}{1} & \multirow[t]{2}{*}{2} & \multirow[t]{2}{*}{3} & \multirow[t]{2}{*}{4} \\
\hline \multirow{3}{*}{ Philosophy } & \multirow{3}{*}{ 1. Constructivism } & & & & & \\
\hline & & $1-2$ & & & & \\
\hline & & $1-3$ & & & & \\
\hline \multirow{11}{*}{$\begin{array}{l}\text { Goals of } \\
\text { learning }\end{array}$} & 2. The Nature of Science & 2 & & & & \\
\hline & \multirow{6}{*}{ 3. Concept Understanding } & $3-1$ & & & & \\
\hline & & $3-2$ & & & & \\
\hline & & 3-3 & & & & \\
\hline & & $3-4$ & & & & \\
\hline & & $3-5$ & & & & \\
\hline & & $3-6$ & & & & \\
\hline & \multirow{3}{*}{ 5. Scientific Thinking Development } & $5-1$ & & & & \\
\hline & & $5-2$ & & & & \\
\hline & & $5-3$ & & & & \\
\hline & 6. Motivation and Interest & 6 & & & & \\
\hline \multirow{8}{*}{ Activities } & \multirow{2}{*}{ 7. Connection } & $7-1$ & & & & \\
\hline & & $7-2$ & & & & \\
\hline & \multirow{3}{*}{ 8. Teaching Strategies/Tools } & $8-1$ & & & & \\
\hline & & $8-2$ & & & & \\
\hline & & $8-3$ & & & & \\
\hline & \multirow{3}{*}{ 9. Cooperation and Communication } & $9-1$ & & & & \\
\hline & & $9-2$ & & & & \\
\hline & & $9-3$ & & & & \\
\hline Assessment & 10. Assessing & 10 & & & & \\
\hline
\end{tabular}

Figure 4: Overall improvement of the physics class during the first cycle of the POCoM.

To obtain quantitative data on the overall improvement, we developed a simple formula to calculate the improvement rate, as shown in Figure 5. Table 3 shows improvement rates by comparing two classes, where " $1 \rightarrow 2$ " means the improvement of the second class compared to the first class. 


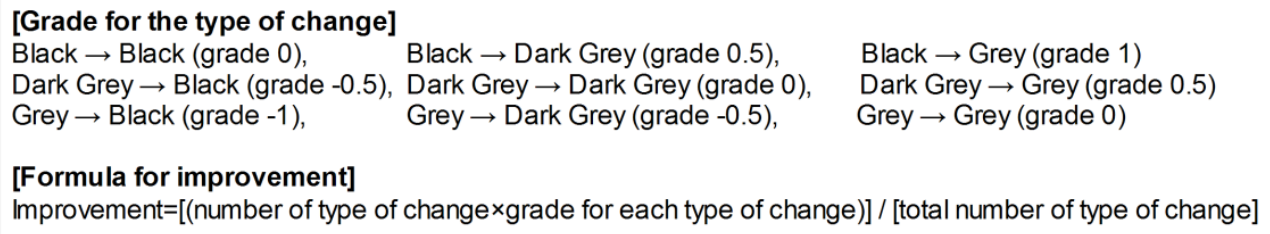

Figure 5: Formula for calculating the degree of improvement.

Table 3. Overall improvement in the first cyclical application of the POCoM (\%).

\begin{tabular}{lcccc}
\hline & \multicolumn{3}{c}{ Step of the class } \\
\cline { 2 - 5 } Class & $\mathbf{1 \rightarrow 2}$ & $\mathbf{2} \rightarrow \mathbf{3}$ & $\mathbf{3 \rightarrow 4}$ & $\mathbf{1 \rightarrow 4}$ \\
\hline Physics & 54 & 27 & 63 & 88 \\
Biology & 50 & 43 & 88 & 96 \\
Earth Science & 44 & 46 & 13 & 65 \\
Average & 49 & 39 & 55 & 83 \\
\hline
\end{tabular}

According to Table 3, the classes in all three subjects showed a final average improvement of $83 \%$, which does not mean the degree of completion, but among the various aspects requiring improvement, $83 \%$ were improved through the efforts of researcher-teacher cooperation.

Second, the average improvements in each step were $49 \%, 39 \%$, and $55 \%$, respectively, indicating gradual and successive improvements rather than abrupt revolutionary change.

Third, the cooperative effort took place over a few days. Therefore, only a few hours or a day passed between classes, meaning that the suggestions were practical and instant.

Fourth, in this study, teaching and learning were improved not by the application of new teaching theories and the training of new teaching skills, but by the activation of teachers' potential but hidden expertise in science teaching. This means that the gap between theory and practice in education is not due to the science teachers'lack of professional knowledge about teaching science but their insufficient use of existing professional knowledge.

Fifth, in this study, the improvements from the application of suggestions were evaluated through qualitative observations by the researchers using the KTOP. Therefore, the suggestions for improvement and evaluations of actual improvements can be subjective, even though five researchers crosschecked the results to reach a consensus. Therefore, the actual improvements need to be verified by other teachers or researchers. Regarding this, as mentioned earlier about the KTOP reliability, an agreement rate of $76 \%-88 \%$ was reached between the researcher and the physics teacher who received training during the in-service course, and there was $72 \%-87 \%$ agreement between the researcher and earth science teachers who received training during the in-service course (Jeong, Park, Park, Kim, \& Park, 2014).

Sixth, each improvement in Table 3 was obtained for one lesson taught four times in different classes. Therefore, we might ask whether the improvement can be shown in other lessons with different contents after a longer time has passed since finishing the cooperation. To answer this question, we applied the POCoM again with the same teachers after 10-50 days. During this interval, there was no interaction between the researcher and teachers. According to Table 4, we found that the results of improvement in the first cycle were similar to the results shown in Table 3. This means that the effect of the POCoM can be obtained in different teaching contents. 
Table 4. Overall improvement in the second cyclical application of the POCoM for the same teacher (\%).

\begin{tabular}{lcccc}
\hline & \multicolumn{5}{c}{ Step of the class } \\
\cline { 2 - 5 } Class & $\mathbf{1} \rightarrow \mathbf{2}$ & $\mathbf{2} \rightarrow \mathbf{3}$ & $\mathbf{3 \rightarrow 4}$ & $\mathbf{1 \rightarrow 4}$ \\
\hline Physics & 54 & 29 & 20 & 70 \\
Biology & 28 & 54 & 83 & 94 \\
Earth Science & 25 & 60 & 83 & 95 \\
Average & 36 & 48 & 62 & 86 \\
\hline
\end{tabular}

Next, we compared the number of KTOP items checked as requiring improvement in the first class of the first and second cycles (Table 5). According to Table 5, the physics and biology teachers (but not the earth science teacher) showed a decrease in the number of KTOP items requiring improvement in the first class of the second application. This means that the improvement effect in the first application can continue to other teaching situations. The interval in this case was only 10-50 days; therefore, to generalize our finding, we need to determine a longer-term maintenance effect.

Table 5. The number of KTOP items requiring improvement in the first class.

\begin{tabular}{lcc}
\hline & \multicolumn{2}{c}{ Number of KTOP items } \\
\cline { 2 - 3 } Class & First cycle of the POCoM & Second cycle of the POCoM \\
\hline Physics & 12 & 6.5 \\
Biology & 14 & 9 \\
Earth Science & 8 & 10 \\
Average & 11.3 & 8.5 \\
\hline
\end{tabular}

Cooperation at the Meeting for Improvement

In this section, we first investigate the reasons that some items on the KTOP were checked as requiring improvement and, second, summarize what improvement ideas or methods were generated through the discussion (Table 6). The parentheses in Table 6 indicate the science subject; for example, " $\mathrm{P}$ " means physics teaching. The sentence before the arrow indicates the researcher's description of the problematic aspect according to the corresponding item on the KTOP. The sentence after the arrow means the ideas for improvement generated through the cooperative discussion for improving the corresponding item on the KTOP checked as requiring improvement.

Table 6. The reasons and suggestions for improvement.

\begin{tabular}{|c|c|c|}
\hline Category & Item & Reason \& Suggestion \\
\hline \multirow[t]{3}{*}{ 1. Constructivism } & $1-1$ & $\begin{array}{l}\text { - There was no encouragement for students' participation in learning, except for textbook reading }(P) \rightarrow \text { Encour- } \\
\text { age students to draw the rays of light themselves on the blackboard and give opportunities for peer evaluation. }\end{array}$ \\
\hline & $1-2$ & $\begin{array}{l}\text { - There was no guidance or metacognitive activity to help students recognize their own learning process }(B) \rightarrow \\
\text { When each step of a learning goal is finished, provide a small activity for the students to reflect on and sum- } \\
\text { marize what they learned (using the activity sheet). }\end{array}$ \\
\hline & $1-3$ & $\begin{array}{l}\text { - The teacher always provided a simple set of information and knowledge, but there was no teacher's support } \\
\text { encouraging students to construct their own understanding }(E) \rightarrow \text { Use statements including misconceptions and } \\
\text { help students recognize whether the statement is correct and develop conceptual understanding by themselves. }\end{array}$ \\
\hline $\begin{array}{l}\text { 2. The Nature of } \\
\text { Science }\end{array}$ & 2 & $\begin{array}{l}\text { - The teacher did not introduce the nature of science (NOS), even though some aspects of the NOS were includ- } \\
\text { ed in the content, such as the zodiac sign, solar, and lunar calendar (E) } \rightarrow \text { Introduce the NOS with statements } \\
\text { such as "Scientists use often varied standards over time" and "Some scientific knowledge is under debate." }\end{array}$ \\
\hline
\end{tabular}




\begin{tabular}{|c|c|c|}
\hline Category & Item & Reason \& Suggestion \\
\hline \multirow[t]{6}{*}{$\begin{array}{l}\text { 3. Concept Under- } \\
\text { standing }\end{array}$} & $3-1$ & $\begin{array}{l}\text { - The teacher did not check what students had learned about "respiration" in the previous class (even though the } \\
\text { current class was closely related to the previous class) (B) } \rightarrow \text { Let students represent what they know about } \\
\text { "respiration." }\end{array}$ \\
\hline & $3-2$ & $\begin{array}{l}\text { - The teacher used scientific misrepresentations, such as "The Sun revolves" (E) } \rightarrow \text { Give explanations such as } \\
\text { "The sun's annual motion does not mean that the sun revolves, even though it appears to move." }\end{array}$ \\
\hline & $3-3$ & $\begin{array}{l}\text { - The teacher introduced difficult concepts such as refraction index and total reflection, which were not included in } \\
\text { the national curriculum }(P) \rightarrow \text { Recommend not including such difficult concepts. }\end{array}$ \\
\hline & $3-4$ & $\begin{array}{l}\text { - The teacher lectured throughout the entire time of teaching }(P) \rightarrow \text { Give opportunities for students to do } \\
\text { something using worksheets, to construct their understanding, evaluate their activities, and discuss among } \\
\text { themselves. }\end{array}$ \\
\hline & $3-5$ & - There was no specific check, comment, or suggestion for improvement. \\
\hline & $3-6$ & $\begin{array}{l}\text { - After teaching the basic concepts of combustion and cellular respiration, the teacher did not give an opportunity } \\
\text { for the students to expand their understanding }(B) \rightarrow \text { Let students present various examples of combustion and } \\
\text { energy application obtained by cellular respiration. }\end{array}$ \\
\hline \multirow{3}{*}{$\begin{array}{l}\text { 5. Scientific Thinking } \\
\text { Development }\end{array}$} & $5-1$ & - There was no specific check, comment, or suggestion for improvement. \\
\hline & $5-2$ & - There was no specific check, comment, or suggestion for improvement. \\
\hline & $5-3$ & $\begin{array}{l}\text { - There is no activity related to enhancing creative thinking }(B) \rightarrow \text { Provide game activities such as "Suggest pos- } \\
\text { sible words that can be linked to 'respiration,' as many and as diverse as possible" (this activity corresponds to } \\
\text { fluency, flexibility, and relational thinking in creativity). }\end{array}$ \\
\hline $\begin{array}{l}\text { 6. Motivation and } \\
\text { Interest }\end{array}$ & 6 & $\begin{array}{l}\text { - There were no specially prepared teaching strategies for enhancing students' interest }(P) \rightarrow \text { Utilize methods } \\
\text { such as simple demonstrations and interesting photos. }\end{array}$ \\
\hline \multirow[t]{2}{*}{ 7. Connection } & $7-1$ & - There was no specific check, comment, or suggestion for improvement. \\
\hline & $7-2$ & - There was no specific check, comment, or suggestion for improvement. \\
\hline \multirow{3}{*}{$\begin{array}{l}\text { 8. Teaching Strate- } \\
\text { gies } \\
\text { /Tools }\end{array}$} & $8-1$ & $\begin{array}{l}\text { - The teacher used role-play activities that were not focused on the main idea and were too time-consuming to } \\
\text { complete }(E) \rightarrow \text { Reduce the number of the activities and emphasize the main idea. }\end{array}$ \\
\hline & $8-2$ & $\begin{array}{l}\text { Even though the various phenomena related to refraction and reflection could be actually observed, the teacher } \\
\text { did not give any opportunities for observation }(P) \rightarrow \text { Encourage the teacher to use relevant multimedia materials } \\
\text { and demonstrations. }\end{array}$ \\
\hline & $8-3$ & $\begin{array}{l}\text { - The activity sheet consisted of mainly "Fill in the parentheses" tasks, which are considered passive learning (B) } \\
\rightarrow \text { Revise the activity sheet to increase students' participation through game activities. }\end{array}$ \\
\hline \multirow[t]{3}{*}{$\begin{array}{l}\text { 9. Cooperation and } \\
\text { Communication }\end{array}$} & $9-1$ & $\begin{array}{l}\text { - There was no group or peer activities }(E \& P) \rightarrow \text { Encourage students to cooperate, discuss, and evaluate their } \\
\text { activities during and after the activities. }\end{array}$ \\
\hline & $9-2$ & $\begin{array}{l}\text { - After students presented their activity results, there were no opportunities for presentations of the results }(B) \rightarrow \\
\text { Let students discuss the similarities and differences between their presentations about combustion and respira- } \\
\text { tion. }\end{array}$ \\
\hline & $9-3$ & $\begin{array}{l}\text { Questions asked by the teacher mainly required simple recall from memory, and the teacher gave the answers } \\
\text { right after the question }(P \& E) \rightarrow \text { Ask questions requiring logical thinking, encourage students to generate } \\
\text { questions, and give opportunities for the students to answer questions by themselves. }\end{array}$ \\
\hline 10. Assessment & 10 & $\begin{array}{l}\text { There was a formative assessment activity, but there was no activity to check the performance results }(P) \rightarrow \\
\text { After completing the formative assessment activity, give opportunities for the students to present their activities } \\
\text { to check their level of understanding. }\end{array}$ \\
\hline
\end{tabular}

In Table 6, only one example of each item on the KTOP is provided, but many other examples are available for each item. All of the examples for each main category of the KTOP are provided in the following summary.

- In Category 1 (Constructivism), teachers usually focused on giving exact explanations through teachercentered lectures; thus, activities to encourage students to participate in learning were rare. To improve these aspects, the suggestions for improvement included more frequent use of activity sheets; asking more questions to help students' understanding; providing opportunities for students' self-directed learning; presenting activity results or ideas; discussing and evaluating students' activities; and facilitating students' activities. 
- In Category 2 (The Nature of Science), the observed teachings showed little relevance to the NOS; however, researchers and teachers tried to relate the NOS with the learning contents.

- In Category 3 (Concept Understanding), teachers sometimes used incorrect everyday language instead of correct scientific terms, gave insufficient explanations, tried to deal with overly difficult concepts that were not included in the national science curriculum, and gave students insufficient opportunities to construct their own understanding. To improve these aspects, the suggestions for improvement included correction of the above mentioned problems; use of the activity sheet and questions requiring deep thinking; and provision of opportunities to students so they may present and discuss their ideas to enhance their own conceptual understanding.

- In Category 5 (Scientific Thinking Development), except for creativity, there were no contents related to the development of scientific thinking and scientific argumentation. To promote scientific creativity, researchers and teachers suggested encouraging students to generate various ideas for fluency and flexibility.

- In Category 6 (Motivation and Interest), when strategies for enhancing motivation and interest are insufficient, the suggestions for improvement included the use of various materials such as photos, movie clips, demonstrations, games, and other interesting activities.

- In Category 7 (Connection), there were no specific checks, comments, or suggestions for improvement.

- In Category 8 (Teaching Strategies/Tools), the suggestions for improvement included the use of activity sheets, appropriate multimedia materials, demonstrations, and various activities such as games or role plays. However, the teacher was encouraged, when using these materials, to focus on the main ideas to be learned in class.

- In Category 9 (Cooperation and Communication), there was almost no small-group activity in the observed classes, no reflections on students' presentations, and no discussion or consensus about the answers to the questions. Therefore, the teacher was encouraged to use relevant activities and questions requiring deep thinking to improve these problems.

- In Category 10 (Assessment), teachers usually conducted formative assessments at the end of class. However, the researchers recommended that the teachers encourage students to present their answers and check their understanding.

\section{The Characteristics of Cases of Improvement}

The teacher applied the improvement methods and ideas generated through the discussion with the researcher to the next class, and the researcher observed the next class using the KTOP to evaluate the effectiveness of the improvement effort. This section analyzes the characteristics of successful improvements and summarizes them into seven types as follows.

Examples from the interviews to identify each type of characteristic of successful improvements are provided below. In the following interview examples, " $R$ " denotes the researcher and " $T$ " the teacher. The symbol " $\leftarrow$ "indicates the corresponding item on the KTOP, and " $\rightarrow$ " indicates how the next class was actually changed.

Type 11: The teacher's agreement is required for the improvement

Even though the basic direction for the improvement was provided by the researcher, we found that the teacher's agreement was required before planning the detailed improvement methods. After agreeing with the basic direction for the improvement, the teacher suggested a concrete teaching plan spontaneously during the cooperative discussion. Then he/she actually prepared the next class with the improvement by him/herself.

Type 12: The teacher often suggests improvement ideas and methods spontaneously during the cooperative effort

During the discussion, the researcher often tried to encourage the teacher to invent his/her own ideas or methods for improvement rather than suggesting them directly. Actually, in many cases, teachers suggested their own improvement ideas or methods, as in the following. 
R: How can you change from teacher-centered to student-centered? $(\leftarrow$ Item 9-2)

T: Group activity ... I can provide an activity sheet for each group and make sure there is one high achiever in each group... Then they can help each other learn... but this [method] can create a distracted learning atmosphere ...

R: If so, ... [I think that] a short activity can be helpful [for focusing students' attention]... What activities can be appropriate [short activities]?

T: Combustion and cellular respiration are ... appropriate ... but they are too simple and uninteresting ... Then, I can let students find various cases regarding combustion [and cellular respiration], discuss [what they found] with each other, and discover the similarities and differences [between them] ...

$(\rightarrow$ In the next class, the researcher observed the revised student group activities, discussion, and presentations)

Type 13: Changing the teacher's teaching style or basic philosophy of teaching and learning requires time and more discussion

Some science teachers had their own teaching styles and philosophies of teaching and learning. Moreover, sometimes they deviated from constructivism or from employing the student-centered approach. In these cases, the researcher had several discussions with the teacher about changing his/her teaching styles and philosophy. After such discussion, the following classes showed much improvement. However, three improvement efforts were insufficient to bring about satisfactory improvement, which means that more time and effort are essential in these cases.

R: Korean teachers usually think that a teacher-centered approach, where the teacher provides full and correct explanations, is the basic method of teaching. Therefore, they continuously explain things for the full hour of class ... but some students do not listen ... $(\leftarrow \quad$ Item 1-3)

T: I think that there is a big difference between what l've learned in the university and actual teaching in class. ... Teaching models do not work, ... Regardless of my explanations ... many students can't understand ... So, I feel I have to give more explanations...

R: But, let us try to give them more opportunities to carry out activities ... [For example], before evaluating the students' activity, why don't you ask students whether they can revise their activity...

(The discussion continued about the basic role of the teacher as a supporter rather than a transmitter of the information in classroom teaching).

$(\rightarrow$ In the following classes, the teacher tried to give students more opportunities to do activities by themselves, and this effort resulted in more students' questions, presentations, and discussions.)

Type 14: Sometimes, continuous encouragement for improvement is required, even though it takes a great deal of time to affect or change actual teaching

As mentioned earlier, we focused on gradual improvement rather than revolutionary change in the POCoM (Figure 1).

(After the first class)

R: You used the worksheet very well. However, you did not check whether students drew [the ray of light] correctly or not ... Why don't you let the students discuss among themselves about what they did, ... you can let them present what they drew first, and have them do a peer evaluation of each other's drawings... I think that that would lead to constructivism. $(\leftarrow$ Item $1-1)$

$T:$... [But] in fact, some students were not interested in this [topic]... However, I will try it next time.

$(\rightarrow$ In the second class, the teacher gave more opportunities for students to work by themselves; however, the teacher's explanation was still dominant.)

(After the second class)

R: It was different from what you expected [because students showed interest and focused on the topic well). The class atmosphere was [unexpectedly] good.

T: [When l observed students' activities] the students drew [the ray of light] well, contrary to my expectations. $(\rightarrow$ In the third class, the teacher let students present their own ideas and read the text by themselves (to summarize the contents), but the teacher did not use peer evaluation. After the cooperation again, students evaluated their peers' activity in the fourth class.)

Type 15: Students' positive responses or active participation motivates the teacher to improve the following class Sometimes, improvement was encouraged by the students' positive responses about the teaching. This was 
an unpredicted yet interesting and important finding, because learning can be viewed as an interaction between the teacher and students.

R: I think that the student's (alternative) idea (in the previous class, a student suggested an alternative analogy different from the analogy introduced by the teacher) was good. That idea can be used to extend the basic idea (about refraction), I think. $(\leftarrow$ Item 8-1)

T: I think so ... I will use his idea in the next class.

$(\rightarrow$ The teacher changed the teaching plan by herself and, in the next class, gave an improved explanation using the student's idea.)

Type 16: Giving correct conceptual explanations or using correct terminology is improved easily

Usually, the educators in an in-service program place great importance on the teachers' correct understanding of the content knowledge. Indeed, this aspect is important; however, in this study, it was not difficult to correct teachers' misunderstanding or incomplete understanding about the content knowledge because of the high-level of competency of Korean science teachers.

Type 17: Underprepared aspects or other technical problems are improved easily

It was frequently observed that teachers did not sufficiently prepare the necessary teaching resources such as relevant photos or PowerPoint files, missed formal steps such as checking previous learning or introducing the next learning topic, or failed in time control. However, these kinds of technical errors could be improved easily.

R: Do you think the students fully understood the material? Why didn't you check their understanding? $(\leftarrow$ Item 10)

T: [Because] the time was limited. [But] I will check the students' understanding next time by properly allocating time.

$(\rightarrow$ The teacher developed the formative test-sheet by herself, and in the next class, she used it and let students present their answers.)

\section{Characteristics of Cases with Unsatisfactory or no Improvement}

The researchers and teachers sometimes failed to improve the science classes to an appropriate degree. As a result, the classes were either partially improved or not at all. Examples from interviews that identify five types of characteristics of unsatisfactory improvements are given below. These characteristics need to be considered for more effective improvement in future cooperation.

Type U1: The teacher's previous unhappy or unsuccessful experiences related to teaching may impede his/her change for improvement

Many educators have indicated that teachers' teaching experiences can determine their teaching skills and styles (van Driel \& Berry, 2010). In this study, it was also observed that teachers' previous experiences affected their current teaching. In particular, unhappy or unsuccessful previous experiences impeded teaching changes.

R: Why don't you use multimedia sources such as PowerPoint files or photos (related to refraction phenomena)? $(\leftarrow$ Item 8-2)

T: When I started teaching, I used PowerPoint materials frequently. However, according to a student satisfaction survey I conducted, the students found PowerPoint to be ineffective in increasing their understanding. After that, I changed to writing on the blackboard instead of using PowerPoint.

$(\rightarrow$ In the next class, the teacher prepared some multimedia sources; however, because he/she did not pre-check the projection TV, it did not work in the class. As a result, he/she failed to use it.)

Type U2: When the teacher ascribes his/her difficulty in teaching to students' traits or faults, improvement may not be easy

For successful teaching and learning, students' responses and condition, such as active participation in learning, and appropriate cognitive level and background knowledge related to the learning are important. Therefore, a teaching plan should consider these aspects. However, in some cases, rather than considering these aspects, a teacher ascribed his/her difficulty in teaching to students' passive attitude toward learning, low cognitive level, or lack of interest. In these cases, the teacher did not try to change his/her teaching actively. 
R: Why don't you give students more time to participate?... There was not enough time to properly check whether their activity was done well. ... [If students have more time for participation], this could lead to constructivism. ( $\leftarrow$ Item 1-1)

T: $\quad$ There are many smart students in the previous class; however, in the next class, many students are not interested in physics, and some students are too lazy...

$(\rightarrow$ Even though the teacher used an activity sheet in the next class, he/she explained everything using a teachercentered approach and did not offer any opportunities for the students to present their ideas on how to catch a fish in water (related to the refraction phenomena.))

Type U3: If the teacher feels pressure to keep up with the curriculum or prepare tests, then improvement may not be easy

Environmental factors and conditions tend to affect teachers' actual teaching. In Korea, all science teachers must cover all the contents in the national science curriculum, and many students are under extreme exam-related stress. Moreover, according to some reports, many Korean teachers complain about having to process too much paperwork. This study found that these kinds of environmental factors can hinder improvement.

R: ... Teachers need to provide students with activities and support their participation in these activities. $(\leftarrow$ Item 1-3)

T: We have to teach the required contents in the textbook... If we employ more activities for student learning, [it will be good], but ... because there is too much content in the textbook ... and because of (entrance and other) examinations ... we cannot [give more activities].

$(\rightarrow$ In the next class, the teacher tried to use activity sheets; however, he/she did not let the students use the activity sheets on their own but rather used them in a teacher-centered approach. Moreover, during the students' activities, there was insufficient teacher support.)

Type U4: When the teacher is not confident in his/her understanding about what to improve, s/he is not willing to improve it

When trying to change the teacher's teaching in the next class after discussing improvements, the researcher observed that the teacher's confidence about what and how to improve was a pre-requisite for making the improvement. That is, if the teacher did not feel the need to change the next class or could not prepare a new concrete teaching plan for the next class, his/her efforts at improvement were unsatisfactory.

(In the first class, the teacher asked simple questions requiring the recall of simple information, repeatedly)

R: To encourage students' participation, why don't you ask more challenging questions? ... That is, you need to ask more challenging questions to help students come up with their own ideas and have them think deeply... $(\leftarrow$ Item 9-3)

T: Yes, ... but, what if the students cannot answer anything because the questions are too challenging, ... or what if they give unexpected answers? Then, how can I manage the situation?

$\rightarrow$ The teacher did not understand the need for challenging questions and was concerned that he/she may be unprepared to respond to unexpected answers. Therefore, she did not present challenging questions in the next class.)

Type U5: Sometimes, the teacher has a specific habit that may be difficult to change

Often, teachers had their own teaching habits. Some of these habits can interfere with students' effective learning. For example, some teachers spoke too fast, used everyday words rather than scientific terminologies, or asked too many simple questions repeatedly without giving the students time to think. In these cases, it was difficult to change their habits.

R: You said "The sun revolves," but the Sun actually does not revolve; it is an apparent motion. Therefore, your representation can confuse students. You need to use exact scientific representations, such as "The sun's annual motion does not mean that the sun revolves, even though it appears to move." $(\leftarrow /$ tem $3-2)$

T: Yes, I will correct it.

$\rightarrow$ The above representation was corrected, but other presentations using everyday words, such as "Because the sun is too fat, ..." were frequently used in the next class.) 


\section{Conclusions and Further Studies}

In today's rapidly changing society, many new educational research results are being published and new educational policies are being announced. Therefore, science teachers need to continuously learn and practice new educational theories and teaching skills in changing situations. In this process, we usually assume that if professors teach pre-service science teachers well, they can apply what they learned to their actual science teaching; as a result, we can expect practical improvement in science teaching and learning. However, this assumption does not always work well.

Therefore, instead of this assumption, we assumed an alternative: Science teachers already have a great deal of knowledge and skills for teaching science. We focused on the link from theory to practice that many educators have emphasized. That is, we tried to activate teachers' hidden expertise or professional knowledge in real science teaching.

Of course, learning new educational theories and drilling new teaching skills is necessary at first. The important point is the next process where teachers apply what they have learned and practiced in their everyday teaching in real classrooms or laboratories (Kretlow, Cooke, \& Wood, 2012; Scheeler, Bruno, Grubb, \& Seavey, 2009). Moreover, there should be a process in which, after the application, we can help teachers recognize which aspects of their teaching need to be improved and how to implement these improvements.

This kind of cyclical process of teacher training, that is, the process of "learn-apply (to real teaching)-analyzeimprove-analyze again-improve again," is an alternative and effective approach to linking theory and practice. To achieve this, we developed and applied the POCoM for the actual improvement of science teaching, and our results showed various positive effects.

Here, we would like to suggest that the POCoM can also be applied to a teaching practicum in a pre-service course as well as an in-service program, as shown in this study. As many educators have emphasized, the teaching practicum is the first experience in which pre-teachers can actually practice what they have learned. As a result, it has an important impact on shaping the nature of teaching. Therefore, in this process, if they experience difficulties linking theory learned at the university with classroom practice, they can set a fixed perspective, such as "theory is not easy to apply in practice" or "theory learned at the university is just theory, and the actual teaching situation is different." Therefore, we recommend the POCoM to help pre-teachers practicalize their theoretical knowledge in the field through the teaching practicum. However, to enhance the effectiveness and practicality of the POCoM, we need to highlight the following points.

First, in this study, we assumed that science teachers already had a great deal of knowledge and skills for science teaching because of the specific Korean situation where students in colleges of education usually study diligently to pass a very competitive national recruitment examination. Moreover, through the improvement of actual science teaching using the KTOP analysis, we claimed that teachers' existing and embedded teaching expertise was activated. However, because this study was not focused on the development of teachers' expertise itself but on actual science teaching in the classroom, we did not analyze the activation and improvement of teachers' teaching expertise. Therefore, we need further studies to investigate the teachers' background knowledge and skills for teaching science and to explore how these are activated and improved through the POCoM application.

Second, in this study, the teachers were ordinary teachers without special training or preparation for classroom teaching; however, the researchers, were experts who prepared the POCoM approach. Therefore, it is necessary to check the applicability of this approach to cooperation efforts between other science educators and science teachers. To check this, we have already applied the approach to other groups of professors and teachers. We obtained a $63 \%$ improvement rate on average from this application, and more detailed results will be presented in the near future.

Moreover, the POCoM can be extended to teacher-teacher cooperation for improving science teaching. To investigate this possibility, we performed another in-service training program for teachers on how to analyze a science class using the KTOP, how to cooperate with colleagues, and how to improve science teaching in a more practical way (Jeong et al., 2014). From this effort, we confirmed that teachers' skills for analyzing science classes could be developed.

Third, in this study, the cooperation was confined to classroom teaching. Therefore, we need to apply our cooperation approach to laboratory teaching as well. In this case, Item 4 in Table 1 should be included to analyze laboratory teaching. This study has also already been conducted, and we also obtained high rates of improvement. These results will also be reported in another article. 
Finally, the number of KTOP items is 23 for classroom teaching and 30 for laboratory teaching. It was not easy to check this many items during observation. According to Table 2, as experts, we analyzed about 11 items on average during the first observation. To increase the feasibility of this approach for ordinary teachers, we need a simplified version of the KTOP. Determining which items should be included and which ones should be omitted on the simplified version may be difficult. To do this, we need to use the full version first in several classroom observations to determine the items that may be omitted. For example, if a teacher continually applies various strategies to encourage students' interest and motivation for learning, then Item 6 (regarding motivation and interest) can be omitted in the simplified version. As a result, an individualized and simplified version of the KTOP can be possible. Further study is necessary to determine the feasibility and effectiveness of a simplified version of the KTOP.

\section{Acknowledgement}

This work was supported by the National Research Foundation of Korea Grant funded by the Korean Government (NRF-2011-32A-B00205).

\section{References}

Banilower, E. R., Boyd, S. E., Pasley, J. D., \& Weiss, I. R. (2005). Lessons from a decade of mathematics and science reform: A capstone report for the local systemic change through teacher enhancement initiative. Chapel Hill, NC: Horizon Research, Inc. Retrieved from http://www.pdmathsci.net/reports/capstone.pdf

Banks, F., Mayes, A. S., Oakes, M., \& Sutton, D. (2001). Teacher early professional development:The context. In F. Banks \& A. S. Mayes (Eds.), Early professional development for teachers (pp. 1-11). London: David Fulton Publishers and the Open University.

Bantwini, B. D. (2010). How teachers perceive the new curriculum reform: Lessons from a school district in the Eastern Cape Province, South Africa. International Journal of Educational Development, 30 (1), 83-90.

Barton, A. C. (1998). Reframing "science for all" through the politics of poverty. Educational Policy, 12 (5), 525-541.

Bednar, A. K., Cunningham, D., Duffy, T. M., \& Perry, J. D. (1995). Theory into practice: How do we link? In G. Anglin (Ed.), Instructional technology: Past, present, and future (2nd Ed.) (pp. 100-112). Englewood, CO: Libraries Unlimited.

Buczynski, S., \& Hansen, C. B. (2010). Impact of professional development on teacher practice: Uncovering connections. Teacher and Teacher Education, 26 (3), 599-607.

Chisholm, L., \& Leyendecker, R. (2008). Curriculum reform in post-1990 Sub-Saharan Africa. International Journal of Educational Development, 28 (2), 195-205.

Davis, K. S. (2002). "Change is hard": What science teachers are telling us about reform and teacher learning of innovative practices. Science Education, 87 (1), 3-30.

Dunbar, K. (2001). What scientific thinking reveals about the nature of cognition. In K. D. Crowley, C. D. Schunn, \& T. Okada (Eds.), Designing for science: Implications from everyday, classroom, and professional settings (pp. 115-140). Mahwah, NJ: Lawrence Erlbaum Associates.

Eijkelhof, H. M. C., \& Kapteijn, M. (2000). ANW: A new course on public understanding of science for senior general secondary education in the Netherlands. In R. T. Cross \& P. J. Fensham (Eds.), Science and the citizen (pp. 189-199). Fitzroy, Victoria, Australia: Arena.

Hascher, T., Cocard, Y., \& Moser, P. (2004). Forget about theory - practice is all? Student teachers' learning in practicum. Teacher and Teaching: Theory and Practice, 10 (6), 623-637.

Hiebert, J., Gallimore, R., \& Stigler, J. W. (2002). A knowledge base for the teaching profession: What would it look like and how can we get one? Educational Researcher, 31 (5), 3-15.

Hoban, G. F. (2005). The missing links in teacher education design: Developing a multi-linked conceptual framework. Dordrecht, the Netherlands: Springer.

Hobson, A. J., Malderez, A., Tracey, L., Giannakaki, M., Pell, G., \& Tomlinson, P. D. (2008). Student teachers' experiences of initial teacher preparation in England: Core themes and variation. Research Papers in Education, 23 (4), 407-433.

Jeong, J-S., Park, J., Park, J., Kim, Y., \& Park, Y-S. (2014). Developing and applying in-service program for spreading the Practical On-site Cooperation Model (POCoM). The Journal of Korean Teacher Education, 34 (3), 261-272.

Johnson, C. C. (2006). Effective professional development and change in practice: Barriers science teachers encounter and implications for reform. School Science and Mathematics, 106 (3), 150-161.

Joram, E., \& Gabriele, A. J. (1998). Preservice teachers' prior beliefs: Transforming obstacles into opportunities. Teaching and Teacher Education, 14 (2), 175-191.

Kearns, D. M., Fuchs, D., McMaster, K. L., Sáenz, L., Fuchs, L. S., Yen, L., Meyers, C., Stein, M., Compton, D., Berends, M., \& Smith, T. M. (2010). Factors contributing to teachers' sustained use of kindergarten peer-assisted learning strategies. Journal of Research on Educational Effectiveness, 3 (4), 315-342.

Korthagen, F. A. J. (2007). The gap between research and practice revisited. Educational Research and Evaluation, 13 (3), $303-$ 310.

Kretlow, A. G., Cooke, N. L., \& Wood, C. L. (2012). Using in-service and coaching to increase teachers' accurate use of researchbased strategies. Remedial and Special Education, 33 (6), 348-361. 
Larkin, D. B., Seyforth, S. C., \& Lasky, H. J. (2009). Implementing and sustaining science curriculum reform: A study of leadership practices among teachers within a high school science department. Journal of Research in Science Teaching, 46 (7), 813-835.

Loughran, J., Berry, A., \& Mulhall, P. (2006). Understanding and developing science teachers' pedagogical content knowledge. Rotterdam: Sense Publishers.

Ostermeier, C., Prenzel, M., \& Duit, D. (2012). Improving science and mathematics instruction: The SINUS Project as an example for reform as teacher professional development. International Journal of Science Education, 32 (3), 303-327.

Park, J., \& Han, S. (2002). Using deductive reasoning to promote the change of students' conceptions about force and motion. International Journal of Science Education, 24 (6), 593-609.

Park, J., Park, Y. S., Kim, Y., Jeong, J. S., \& Park, J. (2014). Korean science teachers' perception about the importance of educational theories/teaching strategies and actual use of it in their schools. Manuscript submitted for publication.

Park, J., Park, Y. S., Kim, Y., Park, J., \& Jeong, J. S. (2014). The development of the Korean Teaching Observation Protocol (KTOP) for improving science teaching and learning. Journal of Baltic Science Education, 13 (2), 259-275.

Penuel, W., Fishman, B. J., Gallagher, L. P., Korbak, C., \& Lopez-Prado, B. (2009). Is alignment enough? Investigating the effects of state policies and professional development on science. Science Education, 93 (4), 656-677.

Putnam, R. T., \& Boroko, H. (2000). What do new views of knowledge and thinking have to say about research on teacher learning? Educational Researcher, 29 (1), 4-15.

Scheeler, M. C., Bruno, K., Grubb, E., \& Seavey, T. L. (2009). Generalizing teaching techniques - From university to K-12 classrooms: Teaching pre-service teachers to use what they learn. Journal of Behavioral Education, 18 (3), 189-210.

Slavin, R. E. (2008). Perspective on evidence-based research in education:What works? Issues in synthesizing educational program evaluations. Educational Researcher, $27(1), 5-14$.

Southerland, S. A., Smith, L. K., Sowell, S., \& Kittleson, J. (2007). Resisting unlearning: Understanding science education's response to the United States's national accountability movement. Review of Research in Education, 31 (1), 45-77.

Supovitz, J. A., \& Turner, H. M. (2000). The effects of professional development on science teaching practices and classroom culture. Journal of Research in Science Teaching, 37 (9), 963-980.

Trianou, A. (2007). Understanding teacher expertise in primary science: A sociocultural approach. Rotterdam: Sense Publishers.

van Driel, J. H., \& Beijaard, D., \& Verloop, N. (2001). Professional development and reform in science education: The role of teachers' practical knowledge. Journal of Research in Science Teaching, 38 (2), 137-158.

van Driel, J. H., \& Berry, A. (2010). Pedagogical content knowledge. In P. Peterson, E. Baker. \& B. McGaw (Eds.), International Encyclopedia of Education (2nd ed.) (pp. 656-661). Paris: Elsevier.

Wallace, J., \& Louden, W. (1992). Science teaching and teachers' knowledge: Prospects for reform of elementary classrooms. Science Education, 76 (5), 507-521.

Jongwon Park

Youngmin Kim

Young-Shin Park

Jongseok Park

Jin-Su Jeong
Ph.D., Professor, Department of Physics Education, College of Education, Chonnam National University, Gwangju, 500-757, Republic of Korea. E-mail: jwpark94@jnu.ac.kr

Ph.D., Professor, Department of Physics Education, College of Education, Pusan National University, Busan, 609-735, Republic of Korea.

E-mail: minkiyo@pusan.ac.kr

Ph.D., Assistant Professor, Department of Earth Science Education, College of Education, Chosun University, Gwangju, 501-759, Republic of Korea. E-mail: parkys@chosun.ac.kr

Ph.D., Associate Professor, Department of Chemistry Education, College of Education, Kyungpook National University, Daegu, 702-701, Republic of Korea.

E-mail: parkbell@knu.ac.kr

Ph.D., Associate Professor, Department of Biology Education, College of Education, Daegu University, Gyeongbuk, 712-714, Republic of Korea. E-mail: jjs@daegu.ac.kr 